\section{Manuscript}

Authors should submit two copies, doublespaced, following either the Chicago Manual of Style or Turabian.

The preferred typewriter elements are: Courier 10, Prestige Elite 12, or Letter Gothic 12.

Hyphenated word breaks should be avoided.

\section{Requests for Donations}

$C \downarrow R L$ News may occasionally print requests for the donation of books or materials to libraries, especially foreign libraries, which have suffered extensive loss through fire, hurricane, or other natural disaster. Other libraries soliciting contributions for other reasons will be referred to the rates for classified advertising in C $U R L$ News.

Editor's Note: These guidelines were adopted by the C\&RL News Editorial Board at the Denver Midwinter Meeting on January 25, 1982.

\title{
Involving classroom faculty in the reference function
}

\author{
By Bonnie Gratch \\ Head/Coordinator of Reference Service \\ Bowling Green State University
}

\section{English instructors answer questions at a special Research Paper Assistance Desk.}

\begin{abstract}
$\mathbf{S}_{\mathrm{i}}$ milar to many medium or large academic libraries, at Bowling Green State University in Ohio we have a course-integrated, research paper skills instructional component in the required English 112 class. Since over 3,000 freshmen enroll in this course during Spring semesters, we have developed a packet of written materials with a self-guided tour, corrected by library support 'staff, and research strategy exercises, corrected by classroom instructors, to completely replace library faculty class presentations. However, observations at the reference desk and a desire to promote increased librarian-student interaction were responsible for a plan to involve ENG 112 instructors and library faculty in a more direct way.

Although the library research paper strategy materials were a help to students, many students
\end{abstract}

still required assistance at the reference desk in researching their paper topics. The volume of questions generated by these students was straining the limits of the reference staff, even with our normal double staffing at peak times. In order to give the freshmen improved service and lighten the load at the reference desk, a separate service location was created.

A small table and chair were placed in the main entrance area across from the reference desk. A sign identified the table location as "ENG 112 Research Paper Assistance" and it listed the hours of staffing. In addition to two library faculty, we recruited two ENG 112 instructors to provide reference assistance six hours a day, five days a week over a five-week period. Reference desk statistics from prior semesters assisted us in selecting the 
time to staff this new service location. An award of $\$ 650$ from the Friends of the Libraries paid for the salaries of the two instructors and the cost of running an advertisement in the student newspaper to further publicize the service.

Training the ENG 112 instructors was accomplished in three sessions. The training was very basic, emphasizing in detail the content of the search

\section{Freshmen identify better with an English instructor.}

strategy materials that the students received; such as, using background sources, the Library of Congress Subject Headings, the card catalogs, and periodical indexes. We made it very clear that we expected them to refer to the reference desk those students who needed more assistance than the ENG 112 instructors could provide.

\section{Evaluation}

As part of a larger evaluation project, we asked ENG 112 students, ENG 112 faculty, and reference librarians about their experiences with and perceptions of the ENG 112 Research Paper Assistance Desk. Overall, the data document very positive reactions to this additional service location. On a scale of $1-5$ with 5 being the best rating, $75 \%$ $(n=42)$ circled a 5 or 4 to indicate that the service was helpful. Ninety-five percent circled 5 or 4 , indicating that the service was courteous. Eightyeight percent of the faculty respondents $(n=34)$ marked "yes" to the statement: "As far as you know, your students received adequate assistance at the ENG 112 Research Paper Assistance Desk." All but one instructor thought that this service should be offered on a regular basis. When analyzing the reference librarians' reactions, all but one of them agreed that a separate service location for ENG 112 students is desirable. However, all six replied that their support for the continuation of this service would depend on having very well trained ENG 112 instructors.

Other data analyzed were the number of questions asked at the two desks (reference and ENG 112 desk). This comparison revealed that the ENG 112 desk staff handled double the amount of questions per day on the average; reference desk handled an average of 17 per day and the ENG 112 desk handled an average of 38 per day. To give one an idea of the range, the greatest number of questions answered in a day at the ENG 12 desk was 63 and at the reference desk the greatest number was 56. The lowest number answered in a day at the ENG 112 desk was four; at the reference desk one day there were no ENG 112 questions answered.

One of the ENG 112 instructors described her experience at the desk in great detail. She felt that the greatest advantage to using ENG 112 instructors was that students identified better with her. This instructor stated, "The students seemed relieved to find a 112 instructor - we gave them someone who could identify with what was happening, and we had the ability to say "well, I tell my students..." She also pointed out that the ENG 112 instructors could better advise students about topic selection and narrowing. All the reference librarians expressed a similar opinion.

\section{What next?}

The experience was definitely worth the efforts required. Certainly, the library gained immensely from a public relations aspect, as the ENG 112 desk idea was perceived by the instructors as a special service for their students. I also believe that the experience of providing research paper reference assistance gave the two instructors a solid appreciation of the range of problems that reference librarians encounter. Both of these instructors made comments which revealed their surprise at some of the research topics that their colleagues had approved, as well as the lack of library research skills demonstrated by many students. If more instructors would have this experience, perhaps their approach to teaching the research paper would be diffrent, particularly the library research component. At the minimum, the lines of communication would be vastly improved.

Certainly, the library faculty could learn a lot more about library research expectations and assumptions made by these instructors. We would also have an improved opportunity to consult with them regarding the design and development of our instructional materials. But do the data and our opinions justify the continuing need for a separate service location for these students?

Perhaps not-not if certain conditions are satisfied. Certainly, the large number of students needing assistance and the data collected do recommend some type of special assistance, but not necessarily a separate service location. Apparently, student respondents who received assistance at the reference desk were just as satisfied, since $76 \%$ circled a 5 or 4 to indicate that the service provided was helpful. The cost of staffing it is considerable, even if only for four to six hours, five days a week. Maintaining a high quality service level is quite demanding, since ongoing training would be required to keep up with the annual turnover of ENG 112 instructors. (These instructors are nearly all graduate teaching assistants or fellows.)

Instead, we could accomplish nearly the same effect by adding a third librarian or a well-trained ENG 112 instructor to the reference desk during the late afternoon and evening periods for the four week peak period of ENG 112 research paper activity. To "personalize" this added assistance for the 
freshmen, we could locate a sign on the reference desk or have the reference desk staff wear buttons that would convey a message inviting ENG 112 research paper questions. In this way our desire to provide service to them would become more visible, just as the separate service location had been. We could also encourage the reference librarians to become more involved with the paper topic selection process. If we hired an ENG 112 instructor to help staff the reference desk, he/she could train us in learning how to better assist students with topic selection questions.

Given our present staffing level and the nature of the library instruction program for the freshman composition course, we will continue to provide this needed research paper assistance as a complement to regular reference service. Next spring we are considering adding a third person to the reference desk to determine if the same level of user satisfaction can be attained as that which was documented at a separate service location.

\title{
Cataloging rare book backlogs
}

\author{
By Jill Harcourt \\ Catalog Librarian \\ University of Oklahoma
}

\section{The rise and fall of a Title II-C grant at the University of Oklahoma's Western History Collections.}

$\mathrm{T}$ of Oklahoma has one of the finest libraries on the Native Americans of North America and the history of the Trans-Mississippi West. The major focus of its collection development is the history of the Southwest and its Native American population. The Collections acquire materials in a wide range of formats, from photographs to manuscripts to microforms and books. In 1982, the Library Division of the Western History Collections had 63,673 volumes (monographs and serials), in both the LC and Dewey classification schemes. The Division also had accumulated an uncataloged backlog of 42,000 volumes.

The inertia of this backlog became so great that the Collections applied for a HEA Title II-C grant. The first-year objectives of this grant were:

1) To catalog and record in national databases approximately one half of the uncataloged published book holdings in the Western History Collections. At the time of application, the uncataloged backlog consisted of 42,000 volumes.

2) To increase the availability and use of the Western History Collections by national and international scholars.

3) To facilitate the bibliographic control of this special research collection by placing our holdings in an in-house circulation system.

4) To aid in the long-range planning and development of the Western History Collections.

5) To strengthen the major national bibliographic systems by inputting the specialized holdings of the Western History Collections into the RLIN and OCLC systems. ${ }^{\text {I }}$

${ }^{1}$ University of Oklahoma Western History Collections. HEA Title II-C (dated January 2, 1982). Strengthening University Research Library Resources Through Bibliographic Access for the Western History Collections. Grant number 6008200688. Project number 091AH20057. 